\title{
UNU-INWEH
}

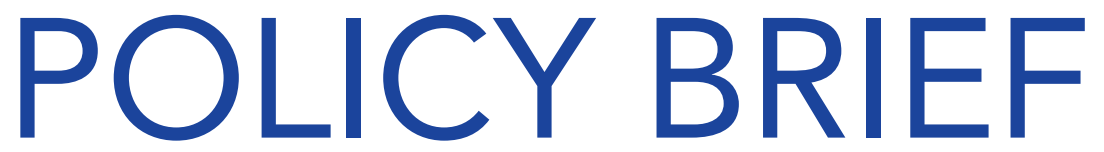

10 UNITED NATIONS

UNU-INWEH

Institute for Water,

\section{WITHOUT WATER, NOTHING IS SECURE}

\section{Water Security and IWRM join forces to deliver effective and measurable SDG plans; country decision makers will benefit from them.}

\section{Key Messages}

- Future innovations that improve water management depend on novel ideas. Framing these around the concept of 'water security' is a strategy that will improve the effectiveness of management and its related policies - benefiting the efforts of countries, as well as local, regional and global water institutions.

- The concept (of water security) is gaining attention on the world stage. Yet, today, there is no agreed understanding, definition and action agenda for water security that is fully supported by the UN. Stakeholders in the water sector can consider the UN-Water Task Force on Water Security's proposed working definition to align their water management priorities and goals.

- As security issues move beyond a limited focus on military risks and conflicts, there is a renewed interest, at UN Security Council level, on water security - despite concerns expressed by some Member States that it may contravene national security, and human and environmental security.

- The underlying message of the Sustainable Development Goals is to 'leave no one behind'. Achieving several of the 17 SDGs will ensure that water is better managed and available for multiple uses. Achieving this will mean that water is secured for all.

- Attempts to measure water security are being made by a number of international organisations and programs. It is deemed important that the concept of water security is operationalised. However, water security may not be just a finite target, but an evolving concept that needs to be adapted to changing circumstances to ensure the best possible outcomes. 
Water is essential to maintaining human and environmental health and well-being, and it is a finite resource. Today, water scarcity affects some $40 \%$ of the global population (UN, n.d.). By 2050, an additional 2.3 billion people are expected to be living in areas with severe water stress (OECD, 2012). To address this ongoing water crisis, decision makers, and national and international organisations are looking for ways to ensure that finite water resources will continue to sustain that planet's human, environmental and economic needs.

Water cuts across multiple sectors, which means that multiple actors are involved in managing it for their own uses. There are calls to develop a common understanding of water security. The working definition proposed by UN-Water is: The capacity of a population to safeguard sustainable access to adequate quantities of acceptable quality water for sustaining livelihoods, human well-being, and socio-economic development, for ensuring protection against water-borne pollution and water-related disasters, and for preserving ecosystems in a climate of peace and political stability (UN-Water, 2013). The group also outlined a water security conceptual framework, which addresses the cross-cutting nature of water and various dimensions that commonly emerge as gaps in the sectoral approach to water management (Figure 1).

\section{Water security, UN and SDGs}

The UN and its Member States are starting to see the value of looking at water through a water security lens. In the past 10 years, two international meetings were held at the UN Security Council to highlight the case that water is linked to security in multiple ways. This is a significant shift in policy thinking, as the term 'security' was typically associated only with national security, in terms of militarisation.

Bringing this broader 'security' context to water serves to create a sense of urgency around the problem. Likewise, the term security, has been added to other resources to create new concepts and a sense of strategic priority, e.g. food security or energy security, which are now well-recognised global issues. Also, the water security concept, including the UN-Water working definition, emphasises the importance of capacity that is needed to achieve this goal.
Water security as a concept, or initiative, opens the opportunity to encourage cooperation between nations. There are some 286 transboundary river basins in the world; shared between two or more countries and covering 62 million $\mathrm{km}^{2}$ (42\% of the Earth's total land area)(TWAP, 2016). While many debates are ongoing around conflict for water, the current and past UN Secretaries General have consistently stated that water must be recognised as a source of cooperation, rather than conflict (UNSC, 2016; UNSC, 2017).

For the coming decade, the world is working to achieve the agreed 2030 Agenda. It is important for all stakeholders to realise that water is the foundation for achieving many of the SDGs. In particular, SDG 6 aims to ensure availability and sustainable management of water and sanitation for all. Water is also specifically mentioned in SDGs 3, 11, 12 and 15, which address health, sustainable cities, consumption, and ecosystems, respectively.

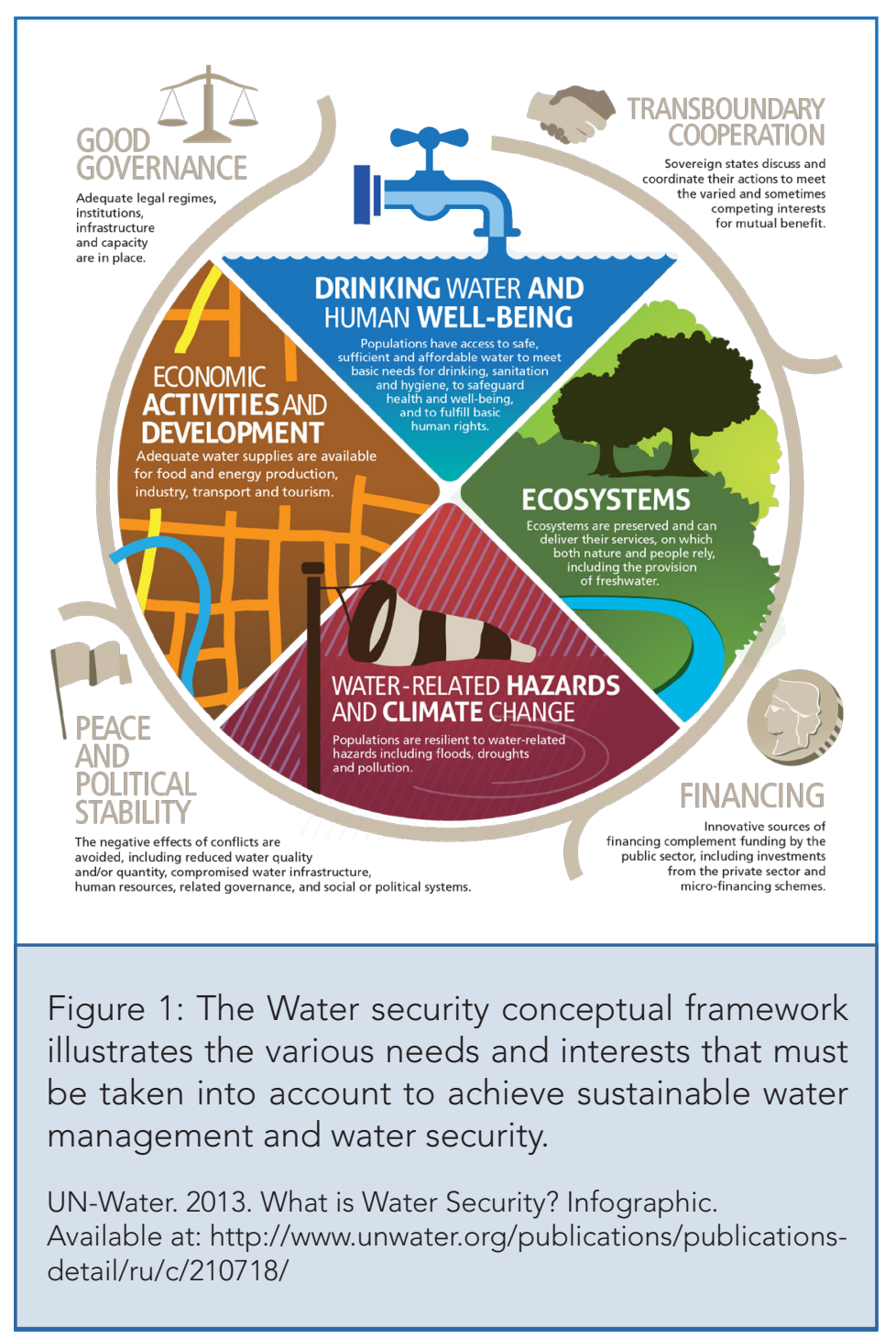


The global agenda for sustainability should be used as a road map and platform to ensure sustainable management of water. This can be effectively planned and measured through a common thinking on water security - between international agencies, regional programs and countries.

The proposed water security conceptual framework is innovative in that it offers entry points into the system through any one of the eight components. Each of these components should be seen as having equal weight in the water security decision making process. But not all components may be relevant to every Member State (Box 1).

\section{Next in the Water Security Agenda}

The water security framework demonstrates it can become a powerful tool and reference to guide policy and finance decisions to help countries address diverse water related issues. Water security is closely linked to the practical approaches of Integrated Water Resources Management (IWRM), a set of tools based on technical and scientific water-related knowledge. IWRM has been adopted by more than $50 \%$ of countries worldwide and is the ideal vehicle for putting water security in action.
A 'common agenda' for water management policies, that follows the water security conceptual framework will effectively address the need to:

- Develop practical tools and indicators to measure the costs and benefits of water-related interventions, while realising the water related SDGs;

- Introduce operational changes and value systems that recognise the true value of water;

- Integrate environmental and social consequences of sustainable water management for managers, policy makers, and users; and

- Provide a platform to exchange data, information, and knowledge on all aspects of water management interventions.

The next step to gain acceptance for water security as a framework and platform for shared policy and decision making is to assess the constraints to its adoption in policy circles. A comprehensive assessment is needed. Panama is an example of a country that shows how the water security framework can align with national goals on sustainable water management.

\section{Box 1: An example of UN Water Security Agenda operationalized by the Member State, Republic}

of Panama

Panama adopted the UN's water security framework to outline a National Plan for Water Security. Consisting of a three-phased approach: short-term (2015-2020), medium-term (2021-2030), and long-term (2031-2050), and five goals, it sets financial targets to achieve these goals. It also calls for the development of a new agency in Panama, CONAGUA (Consejo Nacional del Agua or National Water Council's), to coordinate the activities of multiple agencies, including the Ministry of Environment, Ministry of Economy and Finance, the Ministry of Health, the Ministry of Agriculture, the Panama Canal Authority, the National Authority for Public Services and the Institute for Aqueducts and Water Services. CONAGUA would ensure that various aspects of the water security agenda are suitably addressed and that various government agencies provide the resources needed to achieve the agenda.

The goals of the National Plan:

- Universal access to high-quality drinking water and sanitation services;

- Access to water for socioeconomic growth;

- Preventative approaches to reducing risks associated with water (e.g. floods, extreme weather);

- Watershed-based management of water resources; and

- Strengthening of institutions and both human and financial and resources to ensure sustainability of water resources.

UNDP. 2017. Plan Nacional de Seguridad Hídrica 2015 - 2050: Agua para Todos. Available at: http://www.pa.undp.org/content/panama/ es/home/library/environment_energy/plna_seguridad_hidrica_agua_para_todos.html 


\section{Recommendations}

- A global effort is needed to reach a common understanding - between water managers and users, national and international policy makers and development partners - on a water security framework, and its potential as a powerful tool to effectively implement water-related SDGs.

- Practical implementation of water security requires an approach that considers all eight relevant components outlined in the conceptual framework. One component should not be prioritized over another. This framework is a strong foundation for a common understanding of water security.

- As over $50 \%$ of countries already have national IWRM plans, this is a practical tool to put a water security framework into action. These aspects are highly complementary.

- The lack of capacity is a critical constraint to the widespread adoption of water security approaches. To help address this gap, UNU-INWEH is developing a global training programme (http://wlc.unu.edu/) that ties together the components of the water security agenda. It will be delivered with global and regional institutions and experts. Similar coordinated efforts are needed across developing countries, to strengthen technical and institutional capacity, and knowledge on how to put water security into action.

\section{References}

OECD. 2012. Environmental Outlook to 2050: The Consequences of Inaction, OECD Publishing, Paris. Available at: http://www.oecd.org/ env/indicators-mod-elling-outlooks/oecd-environmental-outlook-1999155x.htm

Transboundary Waters Assessment Programme (TWAP). 2016. River Basins component. Available at: http://twap-rivers.org/\#global-basins United Nations Security Council. 2017. Record of the 7959th Security Council Meeting S/PV.7959. Available at: http://www.un.org/en/ga/ search/view_doc.asp?symbol=S/PV.7959

United Nations Security Council. 2016. Record of the 7818th Security Council Meeting S/PV.7818. Available at: http://www.un.org/en/ga/ search/view_doc.asp?symbol=S/PV.7818

UN-Water. 2013. Water Security and the Global Water Agenda: a UN-Water Analytical Brief. United Nations University. Hamilton, ON, Canada. Available at: http://inweh.unu.edu/wp-content/uploads/2014/05/Water-Security-and-the-Global-Water-Agenda.pdf

United Nations. n.d. Water. Available at: http://www.un.org/en/sections/issues-depth/water/

Authors: Praem Mehta and Nidhi Nagabhatla

Editors: Vladimir Smakhtin, Michael Devlin

Suggested citation: Mehta, P., and Nagabhatla, N. 2017. Without Water, Nothing is Secure. UNU-INWEH Policy Brief, Issue 3. United Nations University Institute for Water Environment and Health. Hamilton, Ontario, Canada.

Photo credit: Nidhi Nagabhatla (cover)

Layout and design: Kelsey Anderson

ISBN: 978-92-808-6085-6

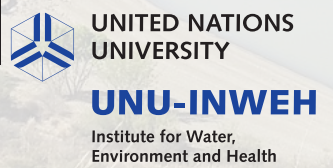

